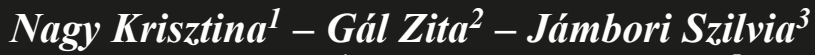 - Kasik László ${ }^{4}$ - Fejes Józssef Balázss
}

${ }^{1}$ SZTE Neveléstudományi Doktori Iskola

${ }^{2}$ SZTE Pszichológiai Intézet

${ }^{3}$ SZTE Pszichológiai Intézet

${ }^{4}$ SZTE Neveléstudományi Intézet

${ }^{5}$ SZTE Neveléstudományi Intézet

\section{A tanulói jóllét és az önértékelés jellemzőinek feltárása középiskolások és egyetemisták körében}

A középiskolás és egyetemi tanulók pszichés állapotának vizsgálata, köztük a szubjektív jóllét fogalma és befolyásoló tényezóinek vizsgálata gyakran megjelenik a pszichológiai és a neveléstudományi kutatásokban. A tanulók iskolához való viszonya befolyásolja iskolai tevékenységeiket, viselkedésüket, a társas kapcsolataik alakulását és a teljesitményüket is. Az iskolai jóllét kialakulását a környezeti tényezók, a tanulók énképe, önértékelése, társas kapcsolatai és iskolai teljesitménye, vagyis elsốsorban a személyi és környezeti tényezók egysége határozza meg. Az iskolához és az iskolai élethez való érzelmi viszonyulás az iskolába lépés kezdetétól folyamatosan változik. Kutatási eredmények igazolják, hogy az iskolába járás pozitív irányú megitélése az életkor elörehaladtával csökken, serdülókorban az iskolai teljesítményelvárások miatt gyakran alakul ki szorongás és félelem (Hascher, 2004, 2008; Réthy, 2016), ami hatással van az iskolán kivüli és az iskola utáni életvezetésre is. Az önértékelésre vonatkozóan hasonló kutatási eredményekról lehet beszámolni,

miszerint az életkor elörehaladtával változó jelenségról van szó, aminek szintje gyermekkorban jellemzóen magasabb, mint serdülókorban, majd a felnóttkori emelkedést követóen idôsebb korban fokozatos csökkenést mutat (Aszmann, 2003; Sallay és mtsai, 2014). Az önértékelés szintje és az iskolához való viszony megitélése esetében összefüggések feltételezhetôk. Vizsgálatunk az önértékelés és a tanulói jóllét életkori jellemzóinek megismerése és a lehetséges összefüggések feltárása. 


\section{Elméleti háttér}

\section{Az önértékelés értelmezése és mérése}

A z énfogalom (szelf, énkép) a személyiségfejlődés egyik központi kérdése, a tanulói énkép és önértékelés alapja. Az énfogalomból szerveződő éntudat az önismeretek és önmotívumok hierarchikus komponensrendszere, melynek segítségével a személy az aktuális habitusához viszonyítva értékelheti, illetve minősítheti önmaga komponenseinek előnyeit, hátrányait, célja a személyiség fejlődőképességének és hatékonyságának biztosítása (Nagy, 2002). Az énkép a személy önmagával kapcsolatos ismereteinek, értékeléseinek és érzelmeinek összessége, amely páros vagy kiscsoportos helyzetekben alakul a társas visszajelzések és a szubjektíven értelmezett visszajelentések mentén. Az énfogalom, énkép egyik leggyakrabban vizsgált rendszere az önértékelés, amelyet az egyén önmagával kapcsolatban megfogalmaz és hosszabb ideig fenntart, szintje azt jelzi, hogy az egyén mennyire tartja magát értékesnek (Körössy, 2004; N. Kollár és Szabó, 2004).

Az önértékelés mint az én (szelf) önértékelö komponense a személyiség- és szociálpszichológia kedvelt témaköre. Az én egy többösszetevős konstruktum, ezért az énértékelés a különböző énösszetevők mentén eltérő lehet, vagyis az önbecsülésnek több formáját lehet megkülönböztetni, melyek közül leggyakrabban a globális és a speciális (specifikus) önbecsülés elkülönítése jelenik meg a szakirodalomban. A globális önbecsülés a személyiség egészére vonatkozó értékminőséget jelenti, kognitív és affektív elemei vannak, a legtöbb eredmény alapján meglehetősen stabil, ami bizonyítja vonásjellegét (nevezik vonásönbecsülésnek) is. A specifikus önbecsülés a személy egyes énösszetevőihez kapcsolódik (V. Komlósi és mtsai, 2017).

Az egyén (a tanuló) önmagáról vélt és gondolt tudattartalmai hosszú fejlődés és tanulás útján fejlődnek és formálódnak, kialakulásában a szülők nevelési stílusa és énképe mellett a szociális visszajelzések és szociális szerepek játszanak jelentős szerepet. A tanulók énképének kialakulását a családi modellnyújtás után az óvodai és iskolai évek alatt kapott tanári és kortárscsoporti visszajelentések biztosítják, ami később az iskolai teljesítményekkel kölcsönhatásban fejlődik tovább, ezért fontos előrejelzője lesz az iskolai tanulmányi sikereknek vagy kudarcoknak (Zsolnai, Kinyó és Jámbori,

Az önértékelés mint az én (szelf) önértékelô komponense a személyiség-és szociálpszichológia kedvelt témaköre. Az én egy többösszetevós konstruktum, ezért az énértékelés a különbözó énösszetevók mentén eltéró lehet, vagyis az önbecsülésnek több formáját lehet megkülönböztetni, melyek közül leggyakrabban a globális és a speciális (specifikus) önbecsülés elkülönítése jelenik meg a szakirodalomban. A globális önbecsülés a személyiség egészére vonatkozó értékminóséget jelenti, kognitiv és affektiv elemei vannak, a legtöbb eredmény alapján meglehetósen stabil, ami bizonyitja vonásjellegét (nevezik vonásönbecsülésnek) is. A specifikus önbecsülés a személy egyes énösszetevóihez kapcsolódik (V. Komlósi és mtsai, 2017). 2012). 
Az iskolakezdés időszakára a gyermekek énképének és önértékelésének alapszerkezete már kialakul, további alakulására az iskolai teljesítmény és annak értékelései játszák az egyik legfontosabb befolyásoló szerepet. A gyermek énképe sérülhet, amennyiben számára kiszámíthatatlan vagy elérhetetlen célokkal kerül szembe. Az önértékelés hatással van a teljesítményre, az iskolai feladatok megoldásában pedig az önbizalom mértékének. Ha az iskolai kudarcok folyamatosan ismétlődnek, akkor a teljesítmény fokozatosan romlik, a kitüzött cél elérésébe és a feladatok megoldásába vetett hit gyengül. Az iskolában a pedagógus személye elhanyagolhatatlan a gyermekek énképének, önismeretének alakulásában, az értékelések esetében az alapos visszajelzés és a megerősítés fontos eszköze a pedagógusnak (Vajda és Kósa, 2005).

Az énképet és az önértékelést már óvodáskortól vizsgálják, az énfogalom a serdülökor felé haladva, a kognitív fejlődéssel párhuzamosan egyre differenciáltabbá válik. A serdülőkorú tanulók bonyolultabb belső tulajdonságaikat is ki tudják fejezni, összetett érzéseket tudnak megfogalmazni, többféle szerepben határozzák meg önmagukat és figyelmüket elsősorban a belső történéseik kötik le (Körössy, 2004). Az önértékelés tehát az életkor előrehaladtával folyamatosan változó jelenséget takar, amely mint stabil vonás-jellegü jellemző az életkorral és a nemmel is összefüggéseket mutat. Az önértékelés szintje gyermekkorban magasabb, mint serdülőkorban, és a felnőttkor során fokozatosan emelkedik (Aszmann, 2003). Az önértékelés szintje összefüggést mutat a stresszel való megküzdés módjával, kedvező hatással van a mentális és fizikai egészség állapotára, serdülőkorban összefüggést mutat a depresszió kockázatával (Sallay és mtsai, 2014). A 9-14 évesek kevésbé gondolkodnak pozitívan saját magukról, önjellemzéseikben a határozottság, a megfontoltság és a kiegyensúlyozottság hiánya jelenik meg, gyakrabban jellemzik magukat negatív tulajdonságaik és gyengeségeik, mintsem erősségeik mentén. A 14-18 éves tanulók vizsgálatából rámutattak, hogy a tanulókat alacsony önértékelés, a szociális kapcsolataikat pedig konfliktusok jellemzik, az önismeret a család társadalmi-gazdasági státuszával mutatott összefüggést (Zsolnai, Kinyó és Jámbori, 2012).

Az önértékelés egyik leggyakrabban alkalmazott mérőeszköze a Rosenberg Önértékelés (/Önbecsülés) Skála (Rosenberg, 1965), amit első publikálása óta számos nyelvre lefordítottak, és amelynek megbízhatósági és érvényességi mutatói a széleskörü felhasználás mellett is megbízhatónak bizonyulnak. A kérdőív pozitív és negatív állítások mentén egydimenziós konstruktumként méri az önértékelést, amely az én (a szelf) önmagával kapcsolatos pozitív és negatív attitüdjeit is tükrözi. A kérdőívet hazai vizsgálatokban is alkalmazták és igazolták megbízhatóságát, validitását (pl. Rózsa és V. Komlósi, 2014; Urbán és mtsai, 2014). V. Komlósi Annamária és munkatársai (2017) ezen mérőeszköz elméleti megalapozásában bemutatják az önértékelés (önbecsülés) lehetséges megközelítéseit. Felhívják a figyelmet a gyakran azonos értelemben használt önbecsülés és önértékelés szavak jelentésbeli különbségeire is. Elméleti összefoglalásuk szerint legygyakrabban a self-esteem (önbecsülés) és a self-evaluation (önértékelés) fogalmaival találkozhatunk, azonban ezen kifejezések jelentése ritkán különül el egymástól, ezért a két fogalmat eme kutatásban is azonos értelmezésben használták. A kutatók szerint az önbecsülés a személy értékelésének pozitivitását fejezi ki, míg az önértékelés a folyamat értékelő minőségére hívja fel a figyelmet.

Sallay és munkatársai (2014) a Rosenberg Önértékelés Skála hazai alkalmazásának módszertani megalapozására tettek kísérletet, ezért kutatásukban az általuk készített lehető legpontosabb fordításban igyekeztek visszaadni a skála eredeti tételeit, ami kutatásuk egyik újszerüségét is jelentette az ezt megelöző, de közel azonos időben publikált vizsgálatokhoz képest. Az adatfelvétel eredményei szerint a kérdöív faktorszerkezete megfelelt a nemzetközileg is többszörösen igazolt bifaktoriális modellnek, az egyes minták közötti összehasonlításban a faktorsúlyok struktúrája stabilnak tekinthető, emellett a 
skála magas belső megbízhatóságot jelzett, és az időbeli stabilitás is megfelelő értéket mutatott. A méröeszköz elméleti és módszertani megalapozottságának köszönhetően jelen kutatásunkban is a Rosenberg Önértékelés Skála segítségével vizsgáltuk az önértékelés jellemzőit.

\section{A tanulói jóllét értelmezése és mérése}

A jóllét fogalma összetett, interdiszciplináris jellegét bizonyítja, hogy több tudományterületen is fellelhető, az elemzések szempontjai alapján sokféle meghatározása létezik. A jóllétet (well-being) a hétköznapi szóhasználatban legtöbbször a boldogság és az elégedettség kifejezésekkel, de többségében pozitív érzelmek és tulajdonságok mentén (pl.: vidámság, jókedv) írják le. A pedagógiai és pszichológiai elemzések eredményei rávilágítanak arra, hogy a jóllét többdimenziós konstruktumként értelmezhetö, amelyet fizikai, pszichológiai, kognitív, szociális és környezeti tényezők egyaránt befolyásolnak. Az értelmezési sokszínűség ellenére az elméletek közös elemeit jelenti az érzelmi tényezők hangsúlyozása, illetve a kognitív és szociális tényezők befolyásoló szerepe, amelyek által az egyénben a saját tapasztalatok és értékelések mentén alakul ki a jóllét élménye, állapota. A kognitív és az affektív tényezők jelentését már eltérően magyarázzák, abban azonban egyetértés mutatkozik, hogy a jóllét nem egy, hanem több tényező mentén rövid és hosszútávon, azaz az aktuális szituáció értelmezéseként és egy folyamat eredményeként is értelmezhető (Hascher, 2004a, 2004b; Pollard és Lee, 2002; Ryff és Keyes, 1995, 1999).

A tanulói és az iskolai jóllét fogalmak gyakran összemosódnak, különbséget általában a vizsgálatok fókuszpontja jelent. A tanulói jóllét elsősorban a tanulót mint különálló szubjektumot helyezi előtérbe, az iskolai jóllét valamivel tágabb értelmezésben, több szempontból vizsgálja a fogalmat (pl. iskolai környezet és légkör, infrastruktúra) (Diener és Lucas, 2000; Hascher, 2008, 2011; Konu és Rimpelä, 2002). Jelen tanulmányban a két fogalmat azonos jelentésben használjuk.

Az iskolai jóllét a szubjektív jóllét iskolai környezetben való értelmezését jelenti. Arra a kérdésre, hogy a tanulók hogyan érzik magukat az iskolában, többféle fogalommal és megközelítéssel adható válasz, az elméleti modellek alapján az iskolai jóllét három dimenzió mentén, az iskolai környezet és feltételek, az egyéni személyiségjegyek és a kettő közötti interakciók mentén értelmezhető. Az iskolai jóllét szoros összefüggésben áll az iskolához való

A tanulói jóllét és az iskolai teljesítmény egymáshoz való viszonya, illetve a jóllét teljesítményre való hatása gyakori kutatási irány. Az eredmények szerint (pl. Vieno és mtsai, 2004) a jóllét szintje közvetlenül nem jelzi elóre az iskolai teljesítményt, viszont a magasabb jólléti mutatókkal rendelkezó diákok jobban teljesítenek az iskolában, és ritkábban vesznek részt kockázatos viselkedésben. Aldridge és munkatársai (2016) az iskolai klima és az iskolai jóllét közötti összefüggéseket vizsgálták, az iskolai klima összetevói mentén eredményeik igazolták, hogy a magas tanulói szubjektiv jóllét nagyobb tanulási motivációt és sikeresebb iskolai tevékenységeket eredményez, aminek köszönhetốen a tanuló iskolához való viszonya is pozitívnak mondható. 
viszonnyal, az iskolai közérzettel, amit a kognitív és affektív tényezők együtt befolyásolnak (Nagy és Zsolnai, 2016; Szabó, Zsadányi és Szabó Hangya, 2015). A tanulói jóllét állapota több tényező mentén szerveződik és folyamatosan változik a tanulókban, ami az iskolai teljesítmény mellett a társas kapcsolatok alakulását és a tanuló önértékelését is befolyásolja (Hascher, 2004, 2008; Pollard és Lee, 2002; Réthy, 2016). Az iskolában átélt negatív élmények, az elvárások következtében kialakult kimerülés, a tanuláshoz és a tanulmányokhoz való negatív attitüd, illetve a hatékonyság és teljesítménycsökkenés megélése a tanulók kiégéséhez vezethet, ami további mentális zavarok kialakulását eredményezheti (Hazag, Major és Ádám, 2010).

A tanulói jóllét és az iskolai teljesítmény egymáshoz való viszonya, illetve a jóllét teljesítményre való hatása gyakori kutatási irány. Az eredmények szerint (pl. Vieno és mtsai, 2004) a jóllét szintje közvetlenül nem jelzi előre az iskolai teljesítményt, viszont a magasabb jólléti mutatókkal rendelkező diákok jobban teljesítenek az iskolában, és ritkábban vesznek részt kockázatos viselkedésben. Aldridge és munkatársai (2016) az iskolai klíma és az iskolai jóllét közötti összefüggéseket vizsgálták, az iskolai klíma összetevői mentén eredményeik igazolták, hogy a magas tanulói szubjektív jóllét nagyobb tanulási motivációt és sikeresebb iskolai tevékenységeket eredményez, aminek köszönhetően a tanuló iskolához való viszonya is pozitívnak mondható.

A jóllét fogalmának egészségügyi oldalról való megközelítése a mai napig jelentős. Konu és munkatársai (2002) iskolai jóllét-modelljüket az egészségi állapotra alapozva a jóllét szociológiai megközelítése alapján állították fel, ami összetettségének köszönhetően az egyik leggyakrabban idézett modellt jelenti napjainkban is (Konu és Rimpelä, 2002; Konu és mtsai, 2002; N. Kollár és Szabó, 2004; Tobia és mtsai, 2018). Az Iskolai Jóllét Modell (School Well-Being Model) az iskolai környezet elemeinek figyelembevételével készült, amelyben az általános jóllét, az oktatás és tanítás, illetve a tanulás és teljesítmény szoros egysége iskolai kontextusban értelmezve adja meg az iskolai jóllét jelentését, külső tényezőként a család és a közösség hat a tanulóra. A jóllét állapotát befolyásoló tényezőket négy dimenzióba sorolták: iskolai körülmények, társas kapcsolatok, személyes tényezők és egészségi állapot (Konu és mtsai, 2002).

Az iskolai jóllét egy további, gyakran idézett elméleti megközelítése Hascher (2004, 2008, 2010) nevéhez füződik, aki az iskolai jóllét fogalmának értelmezésekor a szubjektív jóllét iskolai kontextusban való értelmezéséből indul ki. Elmélete szerint az iskolai jóllét olyan összetett érzelmi állapot, ami az iskolában átélt élmények és tapasztalatok egyéni, érzelmi és kognitív értékelése következtében alakul ki. A jóllét magában foglalja az iskolához való viszonyt is, aminek részét képezik az iskola és a tantárgyak iránti pozitív attitüdök is. Az iskolai jóllét az iskolában átélt élmények hatására változik, kialakulását a környezeti tényezők mellett a tanulók énképe, társas kapcsolatai és iskolai teljesítménye befolyásolja, emellett feltételezi a társas és a fizikai problémák, valamint az iskolai aggodalmak hiányát is. Az értelmezés szerint az iskolai jóllétnek a pozitív és negatív érzelmek mentén objektív (pl.: tanulói teljesítmény) és szubjektív (pl.: személyiség, társas kapcsolatok, aktuális érzések) dimenzióit lehet elkülöníteni, amelyet egyéb környezeti tényezők (pl.: felszereltség) és iskolán kívüli kapcsolatok (pl.: család) befolyásolnak (1. ábra). 


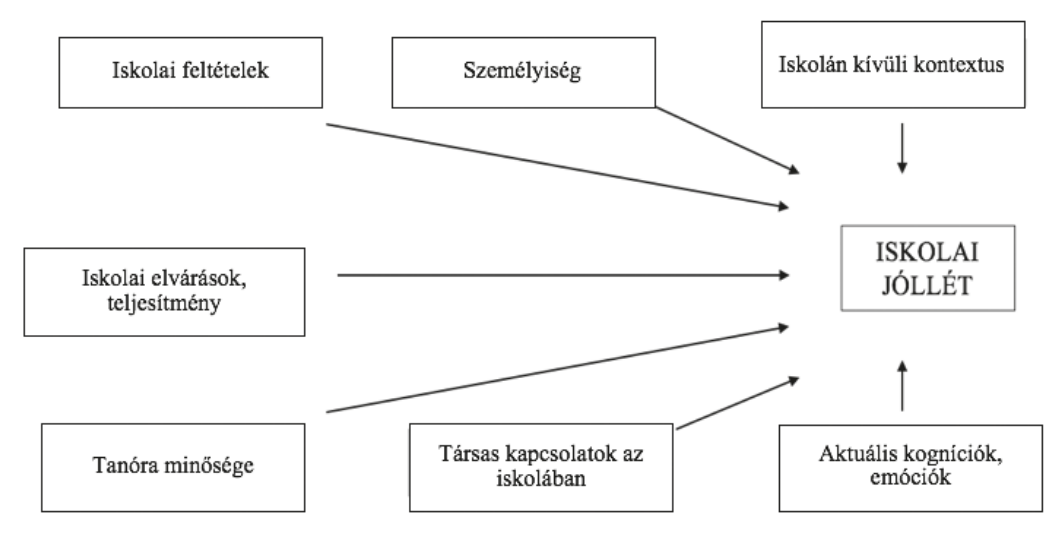

1. ábra. Az iskolai jóllét forrásainak és feltételeinek többszempontú megközelitése (Forrás: Hascher, 2004. 164.)

Hascher (2004) elméletét több nagymintás mérés alapján a saját készítésü, Iskolai Jóllét (Wohlbefinden in der Schule) címet viselő kérdöíve segítségével igazolta (Hascher, 2004, 2008, 2010; Hascher és Lasbang, 2004). A kérdőív először vizsgálja több tényező, illetve pozitív és negatív dimenziók mentén is az iskolai jóllét fogalmát és befolyásoló tényezőit, ezért számít fontos mérőeszköznek a jelenség kutatásában. A jelen tanulmányban bemutatott kutatás keretén belül elkészítettük és először alkalmaztuk a kérdőív magyar nyelvű adaptációját, ezért felépítéséről részletesebben a mérőeszköz bemutatásánál esik róla szó.

\section{Módszerek}

\section{Célok, kutatási kérdések}

A kutatás célja egyrészt a vizsgálatban részt vevő középiskolás és egyetemisták hallgatók önértékelésének, valamint az iskolához kapcsolódó élményei által az iskolai jóllétét meghatározó tényezőinek vizsgálata, emellett a jelenségek feltárására alkalmazott mérőeszközök megbízhatóságának, alkalmazhatóságának igazolása. Kutatási kérdéseinket a vizsgálat tervezésekor egységesen fogalmaztuk meg a vizsgált életkori minták (középiskola és egyetem) vonatkozásában, azonban a későbbiekben a speciálisan (általános vagy közép-) iskolai körülményeket feltételező kérdések többsége miatt az iskolai jóllétet vizsgáló kérdőívet csak a középiskolás tanulók töltötték ki. Kutatási kérdéseinket (egyben hipotéziseinket) a vizsgált mintán az iskolai jóllétre és az önértékelésre vonatkozóan a szakirodalmi háttér alapján fogalmaztuk meg.

A tanulói jóllét vizsgálatára adaptált kérdőív segítségével csak a középiskolás almintán került sor. Feltételeztük, hogy (1) az Iskolai Jóllét Kérdőív (Wohlbefinden in der Schule, Hascher, 2004) az adaptálást követően megfelelö megbízhatósági mutatóval rendelkezik a vizsgált középiskolás mintán, és (2) a kapott faktorok szerkezete azonosságot mutat a nemzetközileg is igazolt konstruktummal. (3) A skálák közötti összefüggések tekintetében az iskolai jóllétet befolyásoló tényezők közül a középiskolás korosztályban a társak hatása és a teljesítményhez való viszony befolyásolja legerőteljesebben az iskolai jóllétet.

Az önértékelés vizsgálatának esetében feltételeztük, hogy (4) a vizsgálatban használt Rosenberg Önértékelés Skála a korábbi hazai és nemzetközi eredményekhez hasonlóan 
jelen vizsgálatban is megfelelő megbízhatósági és érvényességi mutatókkal rendelkezik mindkét részmintán. (5) A szakirodalmi eredmények alapján feltételeztük, hogy a középiskolás tanulók és az egyetemista hallgatók (a fiatal felnőttek) magas önértékelési mutatókkal jellemzik önmagukat, közülük pedig várhatóan az egyetemisták kapnak magasabb összpontszámot. (6) Nemek tekintetében mindkét részmintán a lányok esetében magasabb pontszámokat várunk, mint a fiúktól.

A tanulói jóllét és az önértékelés lehetséges összefüggéseire középiskolás mintán végzünk összefüggés-vizsgálatokat. Feltételezzük, hogy (7) az önértékelés pozitív és negatív faktorai összefüggést mutatnak az iskolai jóllét valamely faktorával, továbbá, hogy (8) azok a tanulók, akik magas önértékeléssel rendelkeznek, jobb tanulmányi eredményességről számolnak be, vagyis a saját teljesítményük megítélése magasabb.

\section{Minta}

Kutatásunkban véletlenszerüen választott dél-alföldi középiskolák 9. évfolyamos tanulói, illetve önkéntes részvétel alapján elsőéves egyetemi hallgatók vettek részt. A vizsgálatot a Pszichológiai Kutatások Egyesült Etikai Bíráló Bizottsága (EPKEB) hagyta jóvá (etikai engedély száma: 2017/125). A középiskolai adatfelvétel az iskolaigazgatók beleegyezésével és csak azon tanulók részvételével történt, akiktől az írásos szülői beleegyező nyilatkozat visszaérkezett, illetve a tanuló is beleegyezett a válaszadásba. A felmérés 2018-ben valósult meg, melyben összesen 164 középiskolás tanuló $\left(\mathrm{N}_{\text {fứ }}=59\right.$, $\mathrm{N}_{\text {lány }}=105$, Átlagéletkor $=14,94$ év) és 184 egyetemi hallgató $\left(\mathrm{N}_{\text {fiú }}=75, \mathrm{~N}_{\text {lány }}=109\right.$, Atlagéletkor=19,66 év) vett részt (összesen 348 fö).

\section{Eljárás}

A tanulóknak a papír-ceruza alapú kérdőívek kitöltésére két tanóra állt a rendelkezésükre, a kitöltés név nélkül történt és az osztályfőnök felügyelete mellett zajlott. Az egyetemisták önkéntes alapon töltötték ki a kérdőívet egy előadáson, ahol 1,5 óra állt a hallgatók rendelkezésére, a válaszokat itt is papír-ceruza alapon, oktató jelenlétében tudták megadni.

\section{Mérőeszközök}

A jelen tanulmányban vizsgált kérdések megválaszolása az Iskolai Jóllét kérdőív (Hascher, 2004) és a Rosenberg Önértékelés Skála (Sallay és mtsai, 2014) válaszai alapján történt. A kérdőívek egy több kérdőívet tartalmazó mérőeszköz-csomag részét képezték, vizsgálatainkat a teljes kérdőívben szereplő háttérváltozók vizsgálatával (pl. nem, életkor, szülők iskolai végzettsége, saját teljesítmény megítélése) egészítettük ki.

Az Iskolai Jóllét Kérdőív (Fragebogen zum Wohlbefinden in der Schule, Hascher, 2004) című kérdőív hat dimenzióban, összesen 33 állításon keresztül vizsgálja a tanulók iskolai jóllétét. A dimenziókat az elméleti háttér alapján érzelmi és kognitív szempontok, illetve pozitív és negatív dimenziók mentén állították össze. A pozitív dimenzióhoz tartozó (1) Pozitív attitűd az iskola felé való pozitív viszonyt, attitüdöt fejezi ki, az (2) Elismerés és öröm az iskolában tapasztalt sikerélményekre, a pedagógusok és a diákok felől érkező elismerésekre és az átélt örömhelyzetekre vonatkozik, az (3) Énkép faktora elsősorban a tanulók tanulmányi teljesítményének megítélésére, az azzal kapcsolatos elégedettségre és a tanuló önbizalmára vonatkozik. A negatív dimenzióhoz tartozó (4) Testi és fizikai panasz az iskolában vagy az iskola miatt kialakult szomatikus tünetekre, a (5) Szociális problémák és konfliktusok az osztály- és iskolatársakkal, valamint a pedagógusokkal kialakult konfliktusokra kérdez rá, az (6) Aggodalom és közöny pedig a tanuló 
tanulás és/vagy iskola iránti közönyét, semlegességét fejezi ki. A dimenziókhoz tartozó itemszámokat példamondattal illusztrálva az 1. táblázat foglalja össze. A kérdöívben a tanulókat (az eredeti kérdőívhez hasonlóan) arra kértük, hogy az elmúlt pár hétre visszagondolva egy hatfokú Likert-skálán jelöljék, hogy milyen gyakran fordult elő velük az adott állítás (soha - szinte soha - néha - gyakran - nagyon gyakran).

1. táblázat. Az Iskolai Jóllét Kérdöiv (Hascher, 2004) felépitése

\begin{tabular}{|c|l|c|l|}
\hline \multicolumn{2}{|c|}{ Dimenziók } & $\begin{array}{c}\text { Item- } \\
\text { szám }\end{array}$ & \multicolumn{1}{|c|}{ Példamondat } \\
\hline 1. & Pozitív attitüd & 7 & Szívesen megyek iskolába. \\
\hline 2. & Elismerés, öröm & 5 & $\begin{array}{l}\text { Az elmúlt pár héten belül elöfordult, hogy egy tanár } \\
\text { megdicsért engem. }\end{array}$ \\
\hline 3. & Énkép & 5 & $\begin{array}{l}\text { Képes vagyok arra, hogy legalább olyan jól } \\
\text { teljesítsem az iskolai feladatokat, mint az } \\
\text { osztálytársaim. }\end{array}$ \\
\hline 4. & Problémák, konfliktusok & 5 & $\begin{array}{l}\text { Az elmúlt pár hétben elöfordult, hogy konfliktusom } \\
\text { volt egy osztálytársammal. }\end{array}$ \\
\hline 5. & Testi, fizikai panasz & 6 & $\begin{array}{l}\text { Az elmúlt pár hétben előfordult, hogy a tanítási óra } \\
\text { alatt megfájdult a fejem. }\end{array}$ \\
\hline 6. & Aggodalom, közöny & 5 & $\begin{array}{l}\text { Az elmúlt pár hétben elöfordult, hogy aggodalom } \\
\text { töltött el az iskola miatt. }\end{array}$ \\
\hline
\end{tabular}

A Rosenberg Önértékelés Skála egy világszerte elfogadott mérőeszköz, több hazai vizsgálatban is alkalmazták már (pl. Urbán és mtsai, 2014; Rózsa és V. Komlósi, 2014). A hazai és nemzetközi kutatásokban kapott eredmények többsége a mérőeszköz megbízhatóságát igazolja, ezért választottuk a saját vizsgálatainkhoz is ezt a kérdőívet. Jelen kutatásban a Sallay és munkatársainak (2014) tanulmányában alternatív fordítási változtatásokkal közölt kérdöívet alkalmaztuk, amely a hazai vizsgálatban már igazolta megbízhatóságát és a faktorszerkezet stabilitását, vagyis a tapasztalatok szerint a kérdőív alkalmas az általános önértékelés szintjének felmérésére. A skála a globális önértékelést négyfokú Likert-skálán, pozitív (pl. „Úgy érzem, értékes ember vagyok, legalább annyira, mint mások.”) és negatív (pl. „Ưgy érzem, nem sok dologra lehetek büszke.”) oldalról megfogalmazott tételekkel, összesen tíz kérdésben vizsgálja.

\section{Eredmények}

\section{A méröeszközök jóságmutatói}

Az alkalmazott kérdőívek jóságmutatói közül mindkét esetben előbb a megbízhatósági mutatókra, majd a faktorelemzések eredményeire térünk ki. Mivel a tanulói jóllétre vonatkozó kérdöívet csak középiskolások töltötték ki, ezért ebben az esetben az eredményeket nem az egyetemisták eredményeivel, hanem az eredeti kérdöív publikált eredményeivel hasonlítjuk össze. Az önértékelés esetében a két részmintának köszönhetően életkori bontásban is összehasonlítjuk az eredményeket és vonunk le következtetéseket.

A kérdőívek megbízhatóságát a Cronbach- $\alpha$ együttható meghatározásával ellenőriztük, az adaptált Iskolai Jóllét Kérdöív reliabilitása a középiskolás mintán ( $\mathrm{N}=143)$ 
megfelelőnek bizonyult (Cronbach- $\alpha=0,79)$. A Rosenberg Önértékelés skála megbízhatósági mutatója a megismert hazai vizsgálatok eredményei alapján való feltételezések szerint igazolódott, mindkét részmintán megfelelönek bizonyult: középiskolás mintán $(\mathrm{N}=164)$ a Cronbach- $\alpha$ értéke 0,89 , az egyetemisták $(\mathrm{N}=188)$ esetében kerekítve szintén 0,89 , és a teljes $(\mathrm{N}=348)$ mintán 0,89 .

A továbbiakban a kérdőívek érvényességét faktoranalízissel vizsgáltuk. Az Iskolai Jóllét Kérdöív esetében eredményeinket először az eredeti kérdőív struktúrájával vetettük össze. Az állítások a nemzetközi eredményekhez hasonlóan esetünkben is hat dimenzióba rendeződtek, azonban tartalmát tekintve eltérések tapasztalhatók az eredeti kérdőívhez képest. A korábbi „Elismerés, öröm” faktora az „Iskolai teljesítmény” elnevezést kapta, mert ebben elsősorban csak a teljesítményre vonatkozó pozitív állítások kerültek bele. A negatív dimenzió esetében az iskolával kapcsolatos általános problémáktól elkülönültek a társakkal való konfliktusok állításai, ezért a korábbi „Szociális problémák, konfliktusok” faktor a „Konfliktusok iskolatárssal, osztálytárssal” nevet kapta. A korábbi itemszámok is eltérően alakultak, ami az állítások dimenziók közötti étrendeződésének köszönhető. A vizsgálatba bevont 33 tétel közül 4 állítást az alacsony értéke miatt kivettünk a további vizsgálatokból, összesen 29 tétellel dolgoztunk a továbbiakban (2. táblázat).

2. táblázat. Az eredeti és a kapott faktorok összehasonlitása itemszámmal

\begin{tabular}{|c|c|}
\hline $\begin{array}{l}\text { Eredeti kérdőív } \\
\text { (itemszám) }\end{array}$ & $\begin{array}{l}\text { Kapott faktorok } \\
\text { (itemszám) }\end{array}$ \\
\hline $\begin{array}{l}\text { Pozitív attitüd } \\
\text { ( } 7 \text { item) }\end{array}$ & $\begin{array}{l}\text { Pozitív attitüd } \\
\text { (6 item) }\end{array}$ \\
\hline $\begin{array}{l}\text { Elismerés, öröm } \\
\text { (5 item) }\end{array}$ & $\begin{array}{l}\text { Iskolai teljesítmény } \\
(5 \text { item })\end{array}$ \\
\hline $\begin{array}{l}\text { Énkép } \\
\text { (5 item) }\end{array}$ & $\begin{array}{l}\text { Énkép } \\
\text { (3 item) }\end{array}$ \\
\hline $\begin{array}{l}\text { Szociális problémák, konfliktusok } \\
\text { (5 item) }\end{array}$ & $\begin{array}{l}\text { Konfliktus iskolatárssal, osztálytárssal } \\
\text { (4 item) }\end{array}$ \\
\hline $\begin{array}{l}\text { Aggodalom, közöny } \\
\text { (5 item) }\end{array}$ & $\begin{array}{l}\text { Aggodalom } \\
(4 \text { item })\end{array}$ \\
\hline $\begin{array}{l}\text { Testi, fizikai panasz } \\
\text { (6 item) }\end{array}$ & $\begin{array}{l}\text { Testi, fizikai panasz } \\
\text { ( } 7 \text { item) }\end{array}$ \\
\hline
\end{tabular}

A kapott változórendszer faktoranalízisre való alkalmasságát a KMO-index értéke $(0,81)$ megerősítette. A kérdőív faktorainak megbízhatósági értékeit a 3. táblázat tartalmazza. Az eredmények azt mutatják, hogy a faktorok fele megfelelő megbízhatóságot jelez, további két faktor értéke alacsonyabb, de még megfelelő megbízhatóságot jelez, a legalacsonyabb értéket az énkép faktora kapta $(0,53)$, ami egyúttal a legkevesebb itemszámot magában foglaló faktor is. A táblázatban szereplő átlagok alapján látható, hogy legnagyobb értéket az iskolai teljesítmény és az énkép, illetve az iskola iránti pozitív beállítódás kapta, a korábbi várakozásokkal ellentétben azonban a középiskolások esetében a társakkal való konfliktus kapta a legkisebb értéket. 
3. táblázat. Az Iskolai Jóllét Kérdöív kapott faktorainak megbizhatósága középiskolás mintán

\begin{tabular}{|l|c|c|c|}
\hline \multicolumn{1}{|c|}{ Faktor neve } & Átlag & Szórás & Cronbach- $\boldsymbol{c}$ \\
\hline Pozitív beállítódás & 3,54 & 1,04 & 0,83 \\
\hline Fizikai, testi panasz & 2,41 & 1,04 & 0,78 \\
\hline Iskolai énkép & 3,34 & 0,89 & 0,53 \\
\hline Konfliktus iskolatárssal, osztálytárssal & 2,16 & 1,28 & 0,82 \\
\hline Iskolai teljesítmény & 3,68 & 0,89 & 0,59 \\
\hline Aggodalom az iskolában & 2,94 & 1,22 & 0,77 \\
\hline
\end{tabular}

A Rosenberg Önértékelés Skála esetében a tételekre adott válaszok mögötti számok összeadásával alakul ki az egyének összpontszáma, a negatív tételek fordított pontozásúak. A KMO-index alapján a középiskolás $(0,91)$ és az egyetemi $(0,89)$ almintán is faktoranalízist végeztünk, a kérdőív feltételezett bifaktoriális szerkezetét az elemzés mindkét almintán igazolta, a megbízhatósági mutatókat a 4. táblázat tartalmazza. Az elemzés során a kérdőívek tételei a pozitív és a negatív állítások mentén két dimenzióba szerveződtek.

4. táblázat. A Rosenberg Önértékelés Skála megbizhatósági mutatói alskálánként

\begin{tabular}{|l|c|c|}
\hline \multirow{2}{*}{ Dimenziók } & \multicolumn{2}{|c|}{ Minta } \\
\cline { 2 - 3 } & Középiskola & Egyetem \\
\hline Pozitív & 0,86 & 0,89 \\
\hline Negatív & 0,85 & 0,84 \\
\hline Teljes minta & \multicolumn{2}{|c|}{0,89} \\
\hline
\end{tabular}

\section{A kérdöivek alskálái közötti kapcsolatok}

Az Iskolai Jóllét Kérdőív skáláinak összefüggéseit vizsgálva több alkalommal a nemzetközi eredményekhez hasonló adatokat kaptunk (5. táblázat). A nagymintás vizsgálatok esetében az aggodalom faktora legtöbbször a testi panaszok és a konfliktusok faktoraival mutatott összefüggést (Hascher, 2004, 2008). Saját eredményeinkben ez szintén megjelent, legtöbb összefüggést, köztük a legerösebb és a leggyengébb összefüggést is az aggodalom faktora esetében találtunk. A faktor a nemzetközi eredményekhez hasonlóan a testi panaszokkal korrelált a legerösebben, legalacsonyabb mértékben az iskolával kapcsolatos pozitív attitüddel. Ezen összefüggés igazolását a szakirodalomban is megtalálható, az iskolában átélt problémák és konfliktushelyzetek (az önértékelés és önbizalom mellett) csökkentik az iskola iránti pozitív attitüdöt, míg az átélt aggodalmak gyakran járnak együtt testi és pszichés panaszokkal. Ha a tanuló nem érzi jól magát az iskolában, akkor nem szívesen vesz részt az iskolai tevékenységekben és az iskola közösségi életében sem (Zsolnai, Kinyó és Jámbori, 2012; Aldridge és mtsai, 2016). 
5. táblázat. Az Iskolai Jóllét Kérdőiv skálái közötti korrelációk

\begin{tabular}{|l|c|c|c|c|c|c|}
\hline & $\mathbf{1 .}$ & $\mathbf{2 .}$ & $\mathbf{3 .}$ & $\mathbf{4 .}$ & $\mathbf{5 .}$ & $\mathbf{6 .}$ \\
\hline 1. Pozitív attitüd & - & & & & & \\
\hline 2. Testi, fizikai panasz & n.s. & - & & & & \\
\hline 3. Konfliktus osztálytárssal, iskolatárssal & n.s. & $0,51^{* *}$ & - & & & \\
\hline 4. Iskolai teljesítmény & $0,46^{* *}$ & n.s. & n.s. & - & & \\
\hline 5. Aggodalom & $0,20^{*}$ & $0,53^{* *}$ & $0,26^{* *}$ & $0,31^{* *}$ & - & \\
\hline 6. Iskolai énkép & $0,39^{* *}$ & n.s. & n.s. & $0,35^{* *}$ & n.s. & - \\
\hline
\end{tabular}

Megjegyzés: $*=p<0,05 ; * *=p<0,01$

A nemzetközi eredményekben az énkép és a pozitív attitüd között gyakran mutatkozott erős vagy közepes összefüggés (Hascher, 2004), mintánkban ezen faktorok közötti korreláció közepes erősségünek bizonyult. Az énkép faktora elsősorban az iskolai tevékenységre és feladatvégzésre vonatkozóan tartalmazott állításokat, ennek lehet köszönhetö, hogy az énkép a pozitív attitüd mellett egyedül az iskolai teljesítménnyel korrelált. Az iskolai teljesítmény és a pozitív attitüd egymással is közepesen erős szignifikáns kapcsolatot mutatott, az összefüggés többszörösen igazolt, miszerint a pozitív iskolai attitűd erősebb motivációt jelent a tanulásra és az iskolai teljesítményre is (Konu és mtsai, 2002; Vieno és mtsai, 2004).

Az osztálytársakkal való konfliktus faktora a testi panaszokkal és az aggodalommal is összefügg szignifikánsan, amire magyarázatot jelenthetnek a pszichés és a fizikai állapot feltételezett összefüggései. Ezek alapján a társakkal kialakult konfliktusok vagy már meglévő konfliktushelyzetek következtében kialakuló stressz, szorongás vagy aggodalom érzése testi és fizikai panaszokat generálhat a tanulóknál (Konu és Rimpelä, 2002; Hascher, 2004).

A kérdőív tételeinek elemzésébe háttérváltozóként a nemet vontuk be a vizsgálatba, azonban a változó nem mutatott szignifikáns összefüggést egyik dimenzió esetében sem, tehát erre vonatkozó következtetéseket a jelen mintán nem tudtunk megállapítani.

Az önértékelés skálán kapott összpontszámok alapján a tanulókat három: alacsony (0-20 pont), közepes (21-30 pont) és magas (31-40 pont) kategóriákba soroltuk az önértékelés megítélésével kapcsolatban. A teljes minta és a részminták esetében is megállapítható, hogy a tanulók többsége magas önértékeléssel jellemezhető $(45,4 \%)$, ezután a közepes (40,3\%), majd az alacsony (12,7\%) kategóriák következnek az előfordulás gyakorisága tekintetében. A szakirodalom áttekintése alapján a középiskolások alacsonyabb önértékeléssel jellemezhetök, mint a fiatalabb korosztályok, esetünkben ilyen összehasonlításra nem volt lehetőség. A szakirodalom szerint fiatal korban az önértékelés is nö, a jelenség folyamatjellegét a mi eredményeink nem támaszthatják alá, de az egyetemi mintán legtöbben a magas (47,3\%), vagy a közepes (41\%) kategóriába sorolhatók.

Az önértékelés skála két tétele (pozitív és negatív) szoros összefüggéseket mutatott, és a korábbi vizsgálatok már részletesen elemezték a kérdőívek szerkezetének koherenciáját (pl. Sallay és mtsai, 2014), ezért azt részleteiben nem elemezzük, helyette egyéb összefüggéseket igyekeztünk feltárni, a vizsgálatba a nemet, az életkort, a szülők iskolai teljesítményét, a saját teljesítmény megítélését és az élettel való elégedettséget vontuk be. A változók közül egyedül a saját teljesítmény megítélése és a nemek esetében kaptunk szignifikáns eredményeket. A nemek esetében középiskolásoknál a fiúk (Átlag fiú $=30,72$; Szórás fiú $=5,9 ;$ Átlag $_{\text {lány }}=26,86$; Szórás ${ }_{\text {lány }}=7,5$ ), az egyetemistáknál a 
lányok (Átlag fiú $=26,79$; Szórás $_{\text {fiú }}=3,4$; Átlag lány $=27,91$; Szórás lány $=3,2$ ) kaptak szignifikánsan ( $\mathrm{F}=2,23 ; \mathrm{p}<0,05)$ magasabb összpontszámokat. A kétmintás t-próba eredményei alapján a középiskolás mintán az önértékelés szintje a teljesítmény megítélésével függött össze szignifikánsan $(\mathrm{F}=2,91 ; \mathrm{p}<0,05)$, vagyis akik a saját bevallásuk szerint átlag feletti iskolai teljesítménnyel rendelkeznek, nekik jellemzően magasabb az önértékelésre adott összpontszámuk is, vagyis magasabb önértékeléssel jellemezhetők. A vizsgálatba bevont egyéb változókkal nem találtunk szignifikáns összefüggéseket.

Az iskolai jóllét és az önértékelés közötti összefüggéseket az eredmények alapján képzett faktorok mentén vizsgáltuk, az önértékelés pozitív és negatív faktorait korrelációvizsgálattal vetettük össze az iskolai jóllét kapott faktoraival (lásd 6. táblázat).

6. táblázat. Az iskolai jóllét és az önértékelés kapott faktorai közötti összefüggések vizsgálata

\begin{tabular}{|c|c|c|c|c|c|c|}
\hline & $\begin{array}{c}\text { Pozitív } \\
\text { attitüd }\end{array}$ & $\begin{array}{c}\text { Testi, } \\
\text { fizikai } \\
\text { panasz }\end{array}$ & $\begin{array}{c}\text { Konfliktus } \\
\text { osztálytárssal, } \\
\text { iskolatárssal }\end{array}$ & $\begin{array}{c}\text { Iskolai } \\
\text { teljesítmény }\end{array}$ & Aggodalom & $\begin{array}{c}\text { Iskolai } \\
\text { énkép }\end{array}$ \\
\hline $\begin{array}{c}\text { Önértékelés } \\
\text { (pozitív) }\end{array}$ & $0,35^{* *}$ & $-0,22^{* *}$ & $-0,26^{* *}$ & $0,18^{*}$ & $-0,16^{*}$ & $0,26^{* *}$ \\
\hline $\begin{array}{c}\text { Önértékelés } \\
\text { (negatív) }\end{array}$ & n.s. & $0,39^{* *}$ & $0,35^{* *}$ & n.s. & $0,43^{* *}$ & n.s. \\
\hline
\end{tabular}

Megjegyzés: $*=\mathrm{p}<0,05 ; * *=\mathrm{p}<0,01$

Az önértékelés pozitív faktora a jóllét valamennyi faktorával, legerősebben a pozitív attitüddel mutatott összefüggést ( $\mathrm{r}=0,35 ; \mathrm{p}<0,01)$. A pozitív önértékelés (a pozitív állításokkal való egyetértés) feltételezheti az iskolához való pozitív viszony meglétét és a tanuláshoz, sikeres teljesítményhez szükséges kellő motivációt (Vajda és Kósa, 2005; Zsolnai, Kinyó és Jámbori, 2012). Az önértékelés pozitív faktora a jóllét valamennyi negatív faktorával (testi panaszok, aggodalom, konfliktus) negatív irányú összefüggést mutatott, ami kifejezi a két jelenség fordított együttjárását, a pozitív önértékelés a konfliktusok, az aggodalom és a testi panaszok hiánya mellett hamarabb kialakul. Ezt igazolja az önértékelés negatív faktorainak a jóllét negatív faktoraival való összefüggése, együttjárása, amely eredmény szintén igazolja a szakirodalom korábbi eredményeit. A önértékelés negatív iránya összefüggést mutat a konfliktusok és a viselkedésbeli problémák előfordulásának gyakoriságával, a testi és pszichés megbetegedések megjelenésével, gyakrabban párosul a stressz érzésével, szélsőséges esetben depresszióval (Sallay és mtsai, 2014).

\section{Összegzés}

Vizsgálataink célja a fogalmak elméleti hátterének megismerése után a tanulói jóllét iskolai környezetben való vizsgálata és az önértékelés jellemzőinek feltárása középiskolás és egyetemista tanulók körében. A tanulói jóllét az iskolai feltételek és a személyiség kölcsönhatása mentén szerveződik és folyamatosan alakul, amiben fontos szerepe van az egyén önértékelésének, önbecsülésének is. A tanulói jóllét magában foglalja az iskolai attitüdöket, az ott kialakult kapcsolatokat és az iskolai légkör szubjektív értékelését, az érzelmi dimenzió kiegészül a kognitív és a fizikai állapot jellemzőivel, az egészség megléte vagy hiánya, illetve az önértékelés mértéke alapvetően változtatja meg az érzelmeket is.

A vizsgálatba bevont kérdöívek müködőképesnek bizonyultak. Az Iskolai Jóllét Kérdöív (Hascher, 2004) magyar nyelven való alkalmazására középiskolás tanulók körében először jelen kutatás kereteiben került sor. Az eredmények több szempontból 
azonosságokat mutattak az eredeti, nemzetközi mintákon már alkalmazott kérdőívvel (faktorok száma, skálák közötti összefüggések), a faktorok szerkezete azonban eltéréseket mutatott, az itemszámok tekintetében és a tételek skálákba szerveződése esetében is átrendeződések figyelhetők meg. Mindez a fordítások további pontosításának szükségességére, a nyelvi különbségek és hasonlóságok közötti különbségek kiküszöbölésére hívja fel a figyelmet. Annak ellenére, hogy a kérdőív megfelelő mutatókkal rendelkezik (Cronbach- $\alpha=0,79)$, és ezáltal igazolta az erre vonatkozó hipotézisünket, a későbbiekben a kérdések pontosításával, a mintanagyság növelésével és a tételekre adott válaszlehetőségek csökkentésével várhatóan jobb eredményeket kaphatunk. A kérdőív negatív és pozitív tartalmú állításai külön faktorokba különültek el, a negatív tartalmú faktorok elsősorban a negatív faktorokkal, a pozitívak a pozitívakkal mutattak összefüggéseket. A faktorok közül a nemzetközi eredményekhez hasonlóan az aggodalom és a konfliktus esetében igazolt a legtöbb összefüggés, az iskolai aggodalom érzése összefügg a konfliktusok előfordulásának gyakoriságával, a teljesítmény csökkenésével vagy a fizikai panaszok előfordulásával. A faktorok átlagainak vizsgálata szerint a legmagasabb értékeket a kérdőív pozitív tételeiből szerveződött faktorok, a teljesítmény megítélése, a pozitív attitüd és az iskolai énkép kapták. Ezen eredmény alátámasztja azt a feltételezést, hogy ezen életkorban az iskolához való viszony és az attitüd alakulásában jelentős szerepe van a teljesítmény megítélésének. A hipotézisekben feltételezett társas hatás pozitív irányú jelentősége nem igazolódott, tekintve, hogy a társakkal kapcsolatos faktorba csak negatív tartalmú állítások kerültek, aminek az értéke pedig a legalacsonyabb átlagértéket kapta.

Az elemzett kérdöívek közül a Rosenberg Önértékelés Skála (Sallay és mtsai, 2014) a hazai és nemzetközi minták tapasztalataihoz hasonlóan esetünkben is magas megbízhatósági mutatókkal rendelkezett mindkét mintán (Cronbach- $\alpha=0,89$ ), és a faktorelemzésekkel a feltételezett bifaktoriális szerkezetet
Az önértékelés pozitív faktora a jóllét valamennyi faktorával, legerósebben a pozitiv attitúddel mutatott összefüggést ( $r=0,35 ;$ p 0,01). A pozitiv önértékelés (a pozitiv állitásokkal való egyetértés) feltételezheti az iskolához való pozitiv viszony meglétét és a tanuláshoz, sikeres teljesitményhez szükséges kelló motivációt (Vajda és Kósa, 2005; Zsolnai, Kinyó és Jámbori, 2012). Az önértékelés pozitiv faktora a jóllét valamennyi negatív faktorával (testi panaszok, aggodalom, konfliktus) negatív irányú összefüggést

mutatott, ami kifejezi a két jelenség forditott együttjárását, a pozitiv önértékelés a konfliktusok, az aggodalom és a testi panaszok hiánya mellett hamarabb kialakul. Ezt igazolja az önértékelés negativ faktorainak a jóllét negativ faktoraival való összefüggése, együttjárása, amely eredmény szintén igazolja a szakirodalom korábbi eredményeit. A önértékelés negativ iránya összefüggést mutat a konfliktusok és a viselkedésbeli problémák elófordulásának gyakoriságával, a testi és pszichés megbetegedések megjelenésével, gyakrabban párosul a stressz érzésével, szélsóséges esetben depresszióval (Sallay és mtsai, 2014). 
igazoltuk. Az önértékelés szintje mindkét almintán magasnak bizonyult, a középiskolások és az egyetemi hallgatók közül is legtöbben a magas önértékelés kategóriájába sorolhatók. A vizsgálatba bevont változók közül a nemek esetében megállapítható, hogy középiskolában a fiúk, az egyetemistáknál pedig a lányok kaptak magasabb pontszámokat az önértékelésnél. A teljesítmény megítélése esetén azon tanulók közül, akik magas önértékelési pontszámot kaptak, többen vallották jónak, kiemelkedőnek az iskolai teljesítményüket.

A jóllét és az önértékelés faktorai közötti összefüggés-vizsgálatok során a szakirodalomban fellelhető összefüggések meglétét tapasztaltuk. Az önértékelés negatív faktorainak a jóllét negatív faktoraival való összefüggése igazolja, hogy az önértékelés negatív iránya magával vonja az iskolához való negatív attitüdök kialakulásának nagyobb valószínűségét, a pozitív irányú önértékelés pedig jobb iskolához való viszonyt és nagyobb tanulási motivációt eredményezhet.

\section{Támogatás}

A kutatást az EFOP-3.6.1-16-2016-00008 azonosítójú,

EU társfinanszírozású projekt támogatta.

A tanulmány elkészítése során Fejes József Balázs

Bolyai János Kutatási Ösztöndíjban részesült.

\section{Irodalom}

Aldridge, J. M., Fraser, B, J., Fozdar, F., Ala'i, K., Earnest, J. \& Afari, E. (2016). Students' perceptions of school climate as determinants of wellbeing, resilience and identity. Improving Schools, 19(1), 5-26. DOI: $10.1177 / 1365480215612616$

Aszmann, A. (2003, szerk.). Iskoláskorú gyermekek egészségmagatartása. Egészségügyi Világszervezet nemzetközi kutatásának keretében végzett magyar vizsgálat. Budapest: Országos Gyermekegészségügyi Intézet.

Diener, E. \& Lucas, R. E. (2000). Subjective emotional well-being. In Lewis, M. \& Haviland, J. M. (szerk.), Handbook of Emotions. New York: Guilford Press. 325-337.

Eder, F. (2002). Unterrichtsklima und Unterrichtsqualität. Unterrichtwissenschaft, 30(3), 213-229.

Hamvai Csaba \& Pikó Bettina (2009). Serdülők szubjektív jóllétét meghatározó tényezők a családban és az iskolában. Új Pedagógiai Szemle, 59(4), 30-42.

Hascher, T. (2004a). Wohlbefinden in der Schule. Münster: Waxmann Verlag.

Hascher, T. (2004b, szerk.). Schule positiv erleben. Bern: Haupt Verlag.

Hascher, T. (2008). Quantitative and qualitative research approaches to assess student well-being. International Journal of Educational Research, 47(2), 84-96. DOI: 10.1016/j.ijer.2007.11.016

Hachser, T. (2010). Subjective Well-Being. In Järvelä, S. (szerk.), Social and Emotional Aspects of Learning, Oxford: Elsevier Academic Press. 99-104.
Hascher, T. \& Baillod, J. (2000). Auf der Schule nach dem Wohlbefinden in der Schule. Schweizer Schule, 87(3), 3-12.

Hascher, T. \& Lobsang, K. (2004). Das Wohlbefinden von Schülerinnen. In Hascher, T. (szerk.), Schule positive erleben. Bern: Haupt Verlag. 203-228.

Hazag Anikó, Major János \& Ádám Szilvia (2010). A hallgatói kiégés szindróma mérése. A Maslach Kiégés-Teszt hallgatói változatának (MBI-SS) validálása hazai mintán. Mentálhigiéné és Pszichoszomatika, 11(2), 151-168

Konu, A. \& Rimpelä, M. (2002). Well-being in schools: a conceptual model. Health Promotion International, 17(1), 79-87. DOI: 10.1093/heapro/17.1.79

Konu, A., Alanen, E., Lintonen, T. \& Rimpelä, M. (2002). Factor structure of the School Well-being Model. Health Education Research, 17(6), 732-742. DOI: $10.1093 /$ her/17.6.732

Körössy Judit (2004). Az énkép összefüggése az iskolai teljesítménnyel. In Mészáros Aranka (szerk.), $A z$ iskola szociálpszichológiai jelenségvilága. Budapest: ELTE Eötvös Kiadó. 83-101.

Nagy József (2002). XIX. század és nevelés. Budapest: Osiris Kiadó.

Nagy Krisztina \& Zsolnai Anikó (2016). Az iskolai kötődés vizsgálata a társas iszonyok aspektusából. In Tóth Péter és Holik Ildikó (szerk.), Új kutatások a neveléstudományokban 2015. Pedagógusok, tanulók, iskolák - Az értékformálás, az értékközvetités és az értékteremtés világa. Budapest: ELTE Eötvös Kiadó. 53-61. 
N. Kollár Katalin \& Szabó Éva (2004). Pszichológiai pedagógusoknak. Budapest: Osiris Kiadó.

Pollard, E. L. \& Lee, P. (2003). Child well-being: a systematic review of the literature. Social Indicators Research, 61(1), 59-78.

Réthy Endréné (2016). Elégedettség, boldogság, jóllét tanuló tanárok körében. Győr: Palatia Nyomda és Kiadó Kft.

Rosenberg, M. (1965). Society and the adolescent self-image. Princeton, NJ: Princeton University Press.

Rózsa Sándor \& V. Komlósi Annamária (2014). A Rosenberg Önbesülés Skála pszichometriai jellemzői: a pozitívan és negatívan megfogalmazott tételek müködésének sajátosságai. Pszichológia, 34(2), 149174. DOI: $10.1556 /$ pszicho.34.2014.2.4

Ryff, C. D \& Keyes, C. L. M (1995). The Structure of Psychological Well-Being Revisited. Journal of Personality and Social Psychology, 69(4), 719-727. DOI: 10.1037/0022-3514.69.4.719

Sallay Viola, Martos Tamás, Földvári Mónika, Szabó Tünde \& Ittzés András (2014). A Rosenberg Önértékelés Skála (RSES-H): alternatív fordítás, strukturális invariancia és validitás. Mentálhigiéné és Pszichoszomatika, 15(3), 259-275. DOI: 10.1556/ mental.15.2014.3.7

Schneider, R. (2005). Klassenklima, Schulklima, Schulkultur - wichtige Elemente einer gesundheitsfördernden Schule. In Regierungspräsidium Stuttgart: Informationsdienst zur Suchtprävention $\mathrm{Nr}$. 18. Gesundheitsförderung durch Schulentwicklung und Schulentwicklung durch Gesundheitsförderung. Eine Handreichung für die Lehrerinnen und Lehrer. Stuttgart: Ministerium für Kultus, Jugend und Sport Baden-Württemberg. 27-40.
Szabó Éva, Zsadányi Zsuzsa \& Szabó Hangya Lilla (2015). Ki szeret iskolába járni? Az iskolai kötődés, a motiváció, az énhatékonyság és a tanulmányifelelősség-vállalás vizsgálata. Iskolakultúra, 25(10), 5-20. DOI: 10.17543/iskkult.2015.10.5

Tímár Éva (1994). Városi és községi iskolák tanítási klímájának sajátosságai. Magyar Pedagógia, 94(3-4), 253-274

Tobia, V., Greci, A., Steca, P. \& Marzocchi, G. M. (2018). Children's Wellbeing at School: A Multi-dimensional and Multi-informant Approach. Journal of Happiness Studies, 19(3), 1-21. DOI: 10.1007/ s10902-018-9974-2

Urbán, R., Szigeti, R., Kökönyei Gy. \& Demetrovics Zs. (2014). Global self-esteem and method effects: Competing factor structures, longitudinal invariance, and response styles in adolescents. Behavior Research Methods, 46(2), 488-498. DOI: 10.3758/ s13428-013-0391-5

Vajda Zsuzsanna \& Kósa Éva (2005). Neveléslélektan. Budapest: Osiris Kiadó.

Vieno, A., Santinello, M., Galbiati, E. \& Mirandola, M. (2004). School climate and well being in early adolescence: A comprehensive model. European Journal of School Psychology, 2(1-2), 219-238.

V. Komlósi Annamária, Rózsa Sándor, S. Nagy Zita, Köteles Ferenc, Sági Andrea \& Jónás Edina (2017). A vonásönbecsülés/-önértékelés kérdőíves mérésének lehetőségei. Elméleti és módszertani konklúziók két önbecsülés/önértékelés kérdőív magyar adaptációja nyomán. Alkalmazott Pszichológia, 17(2), 73-108.

Zsolnai Anikó, Kinyó László \& Jámbori Szilvia (2012). Szocializáció, szociális viselkedés, személyiségfejlődés. In Csapó Benő (szerk.), Mérlegen a magyar iskola. Budapest: Nemzeti Tankönyvkiadó. 327-365.

\section{Absztrakt}

A serdülőkorú és a fiatal felnőttek pszichés állapotának, szubjektív jóllétének és önértékelésének vizsgálata gyakran megjelenik a pszichológiai és a neveléstudományi kutatásokban, a jelenségek egymásra gyakorolt hatása többszörösen igazolt. Az önértékelés, a kép, amit az egyén önmagával szemben megfogalmaz, elsősorban társas környezetben alakul, a család után fontos állomása az iskolai környezet. A tanulói jóllét az iskolában átélt élmények és tapasztalatok szubjektív, érzelmi és kognitív értékelését jelenti, meglétét leggyakrabban a pozitív élmények dominanciájával, az iskolában átélt örömérzettel és az iskolai teljesítménnyel való elégedettséggel írják le. Az iskolához és az iskolai élethez való érzelmi viszonyulás a tanulói önértékeléssel együtt az iskolába lépés kezdetétől folyamatosan változik, ami az iskolai teljesítmény mellett a társas kapcsolatok alakulását is befolyásolja. Az önértékelés szintje serdülökorban alacsonyabb, mint gyermekkorban, azonban a fiatal felnőttkorban ismét emelkedést mutat (Aszmann, 2003; Hascher, 2004, 2008; Pollard és Lee, 2002). Jelen vizsgálat kutatási kérdései kérdőíves adatgyüjtés formájában a vizsgálatba bevont személyek (összesen 355 fö) tanulói jóllétének és önértékelésének jellemzőire vonatkoznak. A kutatás résztvevői közül a középiskolás, 9. osztályos tanulók ( $\mathrm{N}=167)$ az iskolai jóllétet vizsgáló kérdőív magyar változatát (Wohlbefinden in der Schule, Hascher, 2004) és a Rosenberg Önértékelés Skála (Sallay és mtsai, 2014) kérdőíveket töltötték ki, az egyetemista hallgatók (N=188) esetében csak az önértékelés kérdéseire adott válaszokat elemeztük. Az eredmények szerint a kérdőívek jó megbízhatósággal müködtek. A faktoranalízisek az önértékelés esetében a többszörösen igazolt struktúrát igazolták, az adaptált kérdőív esetében a kérdőívtételek átrendeződésének köszönhetően néhány faktor új elnevezést kapott. A korrelációk igazolták az önértékelés magasabb szintjének pozitív iskolai jólléttel való együttjárását. 